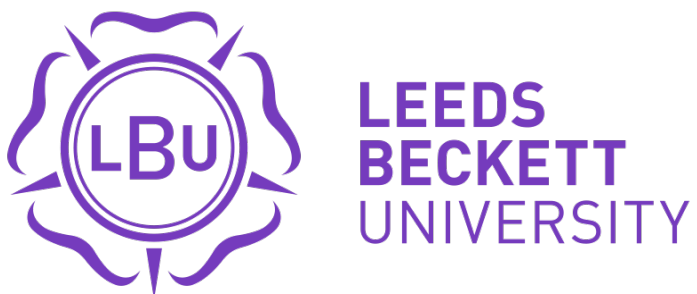

Citation:

El Dief, $M$ and Font, $X$ (2010) The determinants of hotels' marketing managers' green marketing behaviour. Journal of Sustainable Tourism, 18 (2). 157 - 174. ISSN 0966-9582 DOI: https://doi.org/10.1080/09669580903464232

Link to Leeds Beckett Repository record:

https://eprints.leedsbeckett.ac.uk/id/eprint/329/

Document Version:

Article (Accepted Version)

The aim of the Leeds Beckett Repository is to provide open access to our research, as required by funder policies and permitted by publishers and copyright law.

The Leeds Beckett repository holds a wide range of publications, each of which has been checked for copyright and the relevant embargo period has been applied by the Research Services team.

We operate on a standard take-down policy. If you are the author or publisher of an output and you would like it removed from the repository, please contact us and we will investigate on a case-by-case basis.

Each thesis in the repository has been cleared where necessary by the author for third party copyright. If you would like a thesis to be removed from the repository or believe there is an issue with copyright, please contact us on openaccess@leedsbeckett.ac.uk and we will investigate on a case-by-case basis. 


\title{
THE DETERMINANTS OF HOTELS' MARKETING MANAGERS GREEN MARKETING BEHAVIOUR
}

\begin{abstract}
Little is known about the factors underlying the pro-environmental behaviour of marketing managers. This paper explores the determinants of green marketing practices in the Red Sea hotel sector in Egypt. The research model assesses green marketing practices against the personal and organisational values of the marketing managers, together with a range of organisational and demographic variables expected to influence hotels' environmental behaviour. From a valid sample of 89 marketing managers responsible for 194 hotels it was found that organisational contextual variables, and in particular targeting Western tourists, being affiliated to an international hotel chain as well as the marketers' own demographics, including age, academic subject studied, and gender were the best predictors of more pro-active green marketing. Personal environmental values did not explain the pro-environmental environmental behaviour of marketers, and the organisational environmental values that had explained part of their ethical behaviour resulted from voluntarism rather than utilitarian or conformance-based values. Government policies also appeared to be ineffective determinants. The implications for green marketing practices are discussed.
\end{abstract}

Keywords: Accommodation, Hotels, Marketing, Behavioural studies

\section{Introduction}

The last few decades have seen a growing emphasis on environmental protection and the implementation of principles of sustainable development. Within the tourism sector, hotels have been the focus of many actions, not only because of their size and visual presence, but also because of the relatively easy opportunity to reduce impacts while reducing costs and improving the customer experience. Unplanned and uncontrolled hotel development can seriously generate gross environmental degradation. While arguably hotels do not consume vast amounts of environmental resources on an individual basis, collectively they cause considerable impacts on the natural environment (Kirk, 1996; Webster, 2000). The industry's reliance on the physical environment means that the loss of any of these resources is against its own survival and security (González and León, 2001; Kasim, 2006).

The last two decades have brought about significant developments and environmental responsibility is now increasingly becoming part of the corporate agenda. Increased environmental concern on the part of consumers, governments and 
non-governmental organisations has put pressure on the industry to initiate a number of environmental responsibility frameworks, taking the form of voluntary codes of conduct, certification, ecolabels, awards, self-help guides and manuals, and green alliances (Font and Buckley, 2001; Honey, 2002). Developments of this kind fall within strategic planning. It is becoming increasingly important how a hotel firm manages its green reputation and how quickly it responds to growing environmental concern and changes in the market environment. The reviewed literature suggests that a few successful marketing managers, mainly from leading hotel chains in Western Europe and North America, have come to realize the value of green marketing as a tool to position their companies in the market, to differentiate their companies' products and services from those of its competitors and to create trustful relationships with their environmental stakeholders - non-governmental organisations, market intermediaries (e.g. tour operators), the public and most importantly their guests (Kasim, 2008). Research indicates that besides the traditional reputation elements of a firm, environmental responsibility has become central to corporate reputation and competitive success in the marketplace today (Banerjee, 1999; Menon and Menon, 1997; Miles and Covin, 2000; Kärnä et al., 2003; Rivera, 2002). It is concerning, however, to see the expectation that green sells without firms always understanding the market first (Grant, 2007; Key and Popkin, 1998) and much of the literature focuses on doing well by doing good, the holy grail of corporate social responsibility. It is important to understand what characteristics make marketing managers engage with this phenomenon, in order to understand the appropriateness of the messages used, particularly since it is so easy to greenwash (Laufer, 2003), either intentionally or through poor understanding of the issues. However, there is a lack of literature about the implementation of environmental strategies and few studies have addressed 
the impact of the environmental issues on the marketing strategies of business. Thus, this study seeks to contribute to knowledge by empirically identifying the extent to which marketing managers in the Red Sea hotel sector in Egypt have incorporated environmental issues into their firms' marketing strategies, and by evaluating the main factors that underlie different behaviours.

\section{Literature review}

Marketing, by its very definition, takes a utilitarian approach to social responsibility, placing more emphasis on maximizing the wealth of shareholders and owners (Kärnä et al., 2003). To many, marketing epitomises greed and is responsible for impacts arising from over-consumption and overdevelopment, grounded in short-term personal benefits rather than social welfare and quality of life. It is over-zealous marketing by tourism organisations not acknowledging the tragedy of the commons that has attracted mass tourism to eco-sensitive destinations, bringing with it many visible impacts on the social and natural environments (Batra, 2006; Dinan and Sargeant, 2000; Wheeler, 1995). Rather than promoting tourism as a social activity, tourism marketing managers and developers tend to consider it as a source of quick economic growth, focusing solely on the expansion of overall visitor numbers. Such a myopic view of the role of marketing has been the reason for the overdevelopment in many tourist destinations, a situation that have pushed many of these destinations quickly into the declining stage (Batra, 2006).

Marketing can, however, be a vital tool for promoting more eco-friendly patterns of consumption as well as selling new life-styles. Marketing is vast in scope and can, therefore, be improved so as to contribute to finding viable trade-offs between economy and ecology. Sustainability should be the hallmark of a green marketing philosophy (Charter 1992) and for those that believe in working to create 
sustainable businesses, green marketing is the way ahead. Peattie defined green marketing as "the holistic management process responsible for identifying, anticipating and satisfying the requirements of customers and society, in a profitable and sustainable way" (1995: 28). Similarly, Charter conceptualised it as "a holistic and responsible strategic management process that identifies, anticipates, satisfies and fulfils stakeholder needs, for a reasonable reward, that does not adversely affect human or natural environmental well-being" (1992: 141).

Genuine green marketing and sustainability thinking share a holistic view, and proponents of this holistic view stress that green marketing must consider the whole range of activities in which the company is involved (as opposed to greening communications alone, which is greenwashing). Holistically, activities such as planning, new product development, changes to the production process, logistics, packaging, pricing, distribution as well as promotion and advertising should be emphasized in the green marketing process (Chamorro and Bañegil, 2006; Ottman, 1998; Peattie, 1999; Polonsky and Rosenberger, 2001; Wasik, 1996; Welford, 1995). Therefore, green marketing is not merely about the end product. Rather, it must consider the impacts of the entire life cycle of the product, because how a product is developed cannot be isolated from how it is consumed and how it affects the environment (see: Fuller, 1999; Shrivastava, 1995a; Shrivastava 1995b). Without such a vision, the company can be accused of greenwashing. Its portrayal of a green image will backfire, and the environment will not benefit (Grant, 2007; Peattie, 1999).

The literature shows that firms have taken different approaches to green marketing activities (Baker and Sinkula, 2005a; Baker and Sinkula, 2005b; Crane, 2000b; Drumwright, 1994; Hudson and Miller, 2005; Kärnä et al., 2003; Menon and Menon, 1997; Polonsky and Rosenberger, 2001). In many cases, firms claim to 
embrace Business Environmental Responsibility (BER) because they realize that this is the right thing to do and perceive they have a duty to behave in a socially responsible manner- in other cases because they come under stakeholder pressure, and clearly many will fall in between. Firms mostly with the first orientation have modified their entire corporate culture to make sure that environmental issues are incorporated into every aspect of their business. These are rare cases. Empirical hospitality research has, however, shown that altruism is an important motivator for many hotel firms that have been involved in environmental schemes (see: Ayuso, 2006; Rivera and de Leon, 2005; Tzschentke el al., 2004). Many major hotel companies have developed various programmes to protect the environment. For example, in order to improve the monitoring of the environmental performance of its facilities, Hilton Hotels corporate management decided to create Hilton Environmental Reporting (HER), an environmental reporting and benchmarking system for all its facilities (see: Bohdanowicz, 2007). Accor practices the "Earth Guest Program" for preserving and protecting the natural environment and supporting local development. Marriott has implemented the "Green Marriott' program for environmentally responsible hotel operations to support environmental protection and community involvement (see: Lee and Park, 2009). The Rezidor Group has the 'Responsible Business Programme, dedicated to three main areas of responsibility: health and safety of employees and customers; respecting social and ethical issues in the company and the community; and reducing negative impacts on the environment (see: http://www.responsiblebusiness.rezidor.com/).

Unfortunately, not all firms that claim to be environmentally friendly are genuinely green. Some principally exploit the idea to gain greater market share, jumping on the green bandwagon without making any substantive change in their 
environmental actions and performances (Polonsky and Rosenberger, 2001). The most quoted example is claiming to be green by only having a (washing less often) towel and linen agreement. Green marketing has faced a backlash because of its failure to live up to its promises as a tool for promoting ecological and social sustainability. Those misleading green marketing claims -green-washing- lead to consumer scepticism towards all claims, minimising the benefits to truly committed companies who seek to promote the environmental attributes of their products in the marketplace (Chamorro and Bañegil, 2006; Crane, 2000b; Polonsky and Rosenberger, 2001).

The literature contains many different frameworks for green marketing strategies, commonly modelling behaviour around the levels and methods of the integration of environmental issues into a firm's activities (Kärnä et al., 2003; Peattie, 1999; Pujari and Wright, 1996). These are generally inspired by the conceptual ideas and hierarchies of marketing planning presented in textbooks. This research holds that greening the marketing strategy of a hotel business involves decisions at both strategic and functional levels. Strategically, the firm needs to consider the impact of greening on branding, segmenting, targeting, and product positioning. Functionally, green product opportunities must be incorporated into the management of the marketing mix (Font and Carey, 2005). Marketing strategies and functions must be logically associated with each other. If environmental functions are isolated from genuine strategic decisions, firms will not be able to avoid consumers' apathy or distrust, ending up worse off than if they had done nothing (Grant, 2007; Kärnä et al., 2003). True green marketing should, therefore, stem from strong environmental values, which must be internalized in the wider business culture. 


\section{Conceptual framework}

The main focus of this paper is to identify the factors that can affect the implementation of green marketing strategies within the hotel business.

Environmental strategy scholars have suggested a number of possible frameworks to explain how and why some firms adopt proactive environmental strategies.

Stakeholder pressures (Alvarez Gil et al., 2001; Henriques and Sadorsky, 1996; Henriques and Sadorsky, 1999; Sharma and Henriques, 2005), strategic proactivity, (e.g., Aragon-Correa, 1998; Hart, 1995; Porter and van der Linde, 1995; Rivera, 2002; Sharma, 2000), institutional dynamics (e.g. Hoffman, 1999; Rivera, 2004) managerial ethics (e.g. Andersson and Bateman, 2000; Flannery and May, 2000; Prakash, 2001), and organizational context (e.g. Alvarez Gil et al., 2001; Moon and deLeon, 2007; Ramus and Steger, 2000; Sharma, 2000; Sharma et al., 1999) are some of them. Although each has provided a piece of the puzzle, there is as yet no dominant theory or framework. This lack of consistency requires research in this area to draw from multiple theories and bodies of literature.

The approach proposed here applies a multilevel theoretical framework of BER, seeking to enhance our understanding of what catalyzes firms to implement proactive green marketing strategies. The research examines environmental responsibility in marketing strategies at the individual and organizational levels, drawing on theories from psychology, sociology, organizational studies and ethics. The framework explores how individual values might influence environmentally responsible marketing behaviours at work, in order to provide guidance on the kinds of people who might be recruited for situations where BER is particularly desired. This is grounded on the argument that organizational actors may bring their personal commitments and values to work, which may go beyond economic interests or selffulfilment. 
At the early stage of environmental transformation, managerial beliefs, values, attitudes and norms are expected to be potential BER determinants (Rivera and de Leon, 2005), particularly in developing countries where external pressure and regulatory structures may be not fully developed, and where business is considered the most important agency for economic development. Consequently, executives with eco-centric values, who believe that environmental protection is a top priority, may pursue a green agenda within their organizations, leading to the necessary organizational change towards an environmentally friendly culture. This assumption is empirically supported in organisational greening (Andersson and Bateman, 2000; Flannery and May, 2000; Fryxell and Lo 2003; Gonzalez-Benito and GonzalezBenito, 2006) and green marketing literature (Drumwright, 1994).

At the organizational level, the framework distinguishes three dimensions of organizational values: competitiveness (instrumental), legitimacy (relational) and altruism (ethical); and seeks to understand how such value dimensions can lead firms to implement green marketing strategies. Competitiveness, as it relates to the natural environment, explains how firms can search for cost efficiency or market opportunities, hence gaining competitive advantages over their competitors by applying proactive environmental strategies (Porter and van der Linde, 1995, Russo and Fouts, 1997; Shrivastava, 1995b). Legitimacy-based values, however, use environmental actions as means to achieve cordial relations with various stakeholders by adhering to broadly accepted values, norms and regulations (Hoffman, 1999; Marshall et al., 2005; Rivera, 2004). Finally, altruism stems from the argument that some firms reduce environmental impacts because they see this as "the right thing to do" (Bansal and Roth, 2000; Berkhout and Rowlands, 2007; Drumwright, 1994). This broader categorization of BER values is consistent with the ones identified in the 
literature on organisational greening (e.g. Bansal and Roth, 2000; Buil-Carrasco et al., 2008; Gonzalez-Benito and Gonzalez-Benito, 2005a; Gonzalez-Benito and GonzalezBenito 2005b), green marketing (e.g. Baker and Sinkula, 2005a; Baker and Sinkula, 2005b; Kärnä et al., 2003; Menon and Menon, 1997) and corporate social responsibility (e.g. Aguilera et al., 2007) literatures. Overlapping value dimensions are discussed separately for analytical purposes only, as research has shown that firms with more dominant altruistic values may also emphasize a strong willingness to adopt BER initiatives for clear financial benefits and vice versa (Bansal, 2003; Berkhouth and Rowlands, 2007).

\section{Methodology}

The population of marketing managers responsible for 3-4- and 5-star hotels in the Red Sea region (Egypt) was surveyed. These are highly homogeneous and new resort hotels (by average age, and average bed numbers). The population of 3, 4 and 5-star hotels (264 establishments) is represented by 150 marketing managers due the popularity of management contracts and marketing functions at chain level. The Red Sea region was chosen because of both its environmental fragility and its rapid pace of development (Jameson et al., 2007; Shaalan, 2005).

The survey was conducted between June and August 2006using the "drop-off, pick-up method", whereby the researcher visits every marketing manager to explain the purpose of the survey and later on to collect the response. This method is common in Egypt and the Arab world (Mostafa, 2007a; Mostafa, 2007b; Parnell and Hatem, 1999; Rice, 2006a; Rice, 2006b); researchers here encounter difficulties in obtaining random samples because of the lack of sampling frames and the lack of the population's familiarity with research studies. Personal persuasion was needed to encourage response, particularly due to the elite nature of respondents, the novelty of 
the green marketing concept and the potential lack of awareness/knowledge as well as the general negative attitude of business managers in Egypt towards the importance of academic research. 93 of the 150 marketing managers returned the questionnaires, providing a valid sample of 89 questionnaires (59\% of the population), responsible for 194 individual hotel establishments. Instrument design and data analysis are explained with the results for the sake of brevity.

\section{Results}

Following the conceptual framework, the model built to test the determinants of green marketing behaviour took into account a range of variables, outlined below. To measure Personal Environmental Values (PEV), the new revised "NEP" Scale developed by Dunlap et al., (2000), known as the New Ecological Paradigm, was used. Although this scale has been widely tested in different cultures, no published study has used this scale in the Arabic context, until the development of this questionnaire in 2006. Respondents were asked to provide their opinions on the NEP statements using a five-point Likert scale. To shorten the scale, five out of 15 items were deleted based on their low-item total correlations in previous research (Clark et al., 2003; Dunlap et al., 2000; Kotchen and Reiling, 2000). Principal component analysis was applied to the 10 items and two factors turned out to have eigenvalues greater than 1, explaining $59 \%$ of variance in the data. The first factor captured all the anti-NEP items and a pro-NEP item, thus labelled Human Exceptional Paradigm (HEP). The second factor, however, gauged four of the pro-NEP items and was labelled New Environmental Paradigm (NEP). However, Cronbach's $\alpha$ indicated that only the NEP factor exhibited a reliable construct. Checking inter-item total correlations indicated that the item "the earth is like a spaceship with very limited room and resources", a pro-NEP item, had insignificant correlations with the other 
items constituting the HEP subscale. Removing this item, indeed, increased the factor's reliability, achieving a respectable $\alpha$ value of 0.811 . The decision was therefore to reapply a new factor analysis using only 9 items and the results after this procedure are shown in Table 1.

Organisational environmental values (OEV) were measured by asking marketing managers to indicate their degree of agreement or disagreement with 10 statements on a five-point Likert scale, with I being strongly disagree and 5 strongly agree. Statements were chosen so that they represent the three theoretically distinctive determinants of BER mentioned in the model: altruism, competitiveness and legitimisation. The ten items were reduced into two factors through principal component analysis and construct validity (factor loadings) and reliability (Cronbach's $\alpha$ ). The first factor received the strongest loadings on the items referring to the traditional profitability and competitive organisational values. This factor was named "profitability orientation", PO. The second factor tapped four items expressing both altruistic and conformance values. Thus, "voluntary orientation vs. governmental intervention" appeared an appropriate label for this factor: VO vs. GI (see Table 2).

Green marketing strategies (GMS) could not be measured with a single scale from the literature applicable to the hotel industry, although there are various generic scales (Banerjee et al., 2003; Kärnä et al., 2003). The green marketing behaviour of hotels is frequently measured within environmental management scales with no more that one or two items on ecological arguments in marketing campaigns (CarmonaMoreno, 2004). A scale was developed and adapted from the general green marketing research (Banerjee et al., 2003; Kärnä et al., 2003) to suit the hotel context. Respondents were asked to assess the extent to which environmental issues have impacted their firms' marketing strategies and/or functions, using a five-point Likert- 
type scale. Following Kärnä et al., (2003), the nine items included in this scale were divided into two constructs - green marketing strategies and functions. Principal component analysis however reduced these to a single construct, with an $\alpha$ Statistic of 0.89 (Table 3). This indicates that companies implementing environmental management strategies also emphasized environmental issues in their marketing functions and vice a versa.

Insert Tables 1, 2 and 3 about here

Several organisational and demographic variables were included as controls for the purposes of (1) determining the unique contribution of personal and organisational values, (2) describing the participants, and (3) assessing generalisability. The following demographic and organisational information was collected: 1) A firm's degree of internationalisation, was included because the literature suggests that international chain hotels are more likely to implement environmental strategies due to the effects of economies of scale, marketing experience in markets where green differentiation is possible, and the possible transfer of environmental knowledge among affiliates (Ayuso, 2006; Bohdanowicz, 2006; Gonzalez and Leon, 2001). 2) The target market was included because the literature suggests that customers, particularly Western European, are more likely to influence companies' environmental behaviour (Ayuso, 2006). Environmental psychology scholars also confirm the relevance of this variable, arguing that citizens from wealthier countries are likely to put higher emphasis on environmental issues (Diekmann and Franzen, 1999; Kemmelmeier et al., 2002). 3) Managers' age was included as the era in which one is brought up is arguably central to shaping 
environmental values, attitude and behaviours (Fryxell and Lo, 2003; Rivera and de Leon, 2005). 4) Gender was also controlled because previous research suggest that females are more likely to endorse the NEP than males (Deng et al., 2006; Egri and Herman, 2000; Snelgar, 2006). 5) The academic major was included given its obvious relationship to strategic environmental behaviour (Ewert and Baker, 2001; Rivera and de Leon, 2005). 6) Manager's industry tenure was included as a control variable due to its relevance to corporate strategic change (Wiersema and Bantel, 1993). While company's type of ownership and manager's nationality were considered, these were not useful as controls as $94 \%$ reported being privately owned and only three marketing managers were non-Egyptians.

Variables were analysed for multi-collinearity (Table 4) showing ten determinant variables. Pearson bivariate correlations indicate multi-collinearity would make it difficult to assess the individual importance of a predictor. For example, international chain hotels on the Red Sea tend to target Western European markets, to have more environmentally conscious managers, to employ females and to be more driven by voluntarism in environmental responsibility and/or put less emphasis on governmental intervention. Thus, in order to avoid interpretation problems, the ten predictors were hierarchically entered into three regression models. The first incorporated only the control variables as predictors, the second model regressed the two dimensions of PEV against the GMS variable, while the third included, the two dimensions of OEV. The results from the hierarchical models are provided in Table 5, and form the basis of the discussion.

Insert Table 4 and 5 about here 


\section{Discussion}

The first model incorporated only the control variables. The explanatory $\left(\mathrm{R}^{2}\right)$ was significant, suggesting that the inclusion of these predictors into this analysis was appropriate. Targeting West European markets stood out as the most powerful predictor of GMS, implying that marketing managers believed these markets to expect, prefer or demand environmentally friendly hotel products and thus differentiation strategies are needed. This finding is consistent with Ayuso's (2006) suggestion that customers' environmental concerns depend to a great extent on their nationality, with Western Europeans being more willing to collaborate in environmental initiatives. Empirical evidence reveals that customers in developed countries have influenced companies in China to comply and adopt the ISO 14001 EMS standard (Christmann and Taylor, 2001). Interestingly, this was the only predictor with a beta coefficient above $99 \%$ confidence in all three hierarchical models. However, according to table 4, targeting these markets was greater in companies belonging to international chains implying that the explanatory power of this variable might be to some extent capturing the importance of a firm's degree of internationalization.

Chain affiliation provided positive and significant coefficients in all three regressed models, with international chains being the most proactive. This might be attributed to the effects of the economies of scale, which may enable international companies to respond quicker to changes in the market environment. Experience in markets where green attributes are either hygienic factors or differentiation strategies is another possible explanation. Regardless of their size, subsidiaries of multinationals have greater visibility than domestic firms, attracting greater public scrutiny and higher expectations of environmental pro-activity. Therefore, subsidiaries of multinationals are more likely to adopt proactive environmental strategies to maintain 
their legitimacy and credibility in the eyes of their stakeholder. Alternatively, it might be the case that parent company's wider-policies impose a minimum level of communication content as reputation standard on affiliates. These results are, therefore, consistent with earlier research concluding that international chain affiliation enables hotels to deploy more extensive environmental practices (Ayuso, 2006; Bohdanowicz, 2006).

The manager's academic major and age revealed a significant relationship with GMS, while industry tenure and gender did not (see table 5). Overall, environmental emphasis in marketing strategies was stronger in companies run by marketing managers majoring in business than those in hospitality and science - both were insignificant. This may be attributed to the nature of business studies where marketing and organisational behaviour courses are often studied in more depth than in other degrees, particularly in Egypt. Having a stronger background in a particular field may enhance the understanding of new concepts related to that field much more than when one is only aware of its basics. Marketing managers with a business background can be expected to be more aware of changes in market preferences and demands. The background and knowledge of top decision-makers was found to be associated with hotels' decisions to adopt voluntary environmental programmes in Costa Rica (Rivera and Leon, 2005).

Results of this analysis also showed that companies with younger marketing managers are more likely to incorporate environmental issues into their marketing strategies. Younger marketing managers seemed to be more curious, flexible and willing to import new concepts into their organisations to prove efficiency and merit of job position. This was the only possible explanation, since there were no intergenerational differences among respondents of this sample regarding adherence of 
NEP. As the sample averaged 36 years old, with two thirds younger than 40, one can also speculate the influence of Internet and exposure to other communication technologies on younger staff. This finding is also consistent with Cummings' work (2008), who concluded that younger managers, from China, Indonesia and Australia are more likely to embrace environmental initiatives.

The findings thus imply that the individual manager would be more influential in promoting environmental issues if he/she can also provide factual knowledge about the benefits of such issues. The literature has already shown that lack of knowledge and know-how can be a reason that invalidates the discretion of a manager (Hambrick and Finkelstein, 1987) and thus his/her ability to influence the firm's environmental performance (Aragon-Correa et al., 2004).

The influence of PEV on green marketing behaviour was tested in the second model of the hierarchical regression procedure (Table 5). The high endorsement for the NEP scale ( $M=4$ out of 5) could be the result of socially desirable responses (Akaah and Lund, 1994; Fryxell and Lo, 2003) and is consistent with recent studies reporting high level of endorsement of NEP in Egypt (Mostafa, 2007a; Mostafa, 2007b; Rice, 2006b). In practice, PEV did not explain a portion of the overall variance in marketing decisions on behalf of the environment. This contradicts the findings from developed countries, where environmental champions and personal leadership are pointed to as crucial to environmental engagement (Andersson and Bateman, 2000; Drumwright, 1994), particularly in management where the range of proenvironment actions available is greater, and many lead to eco-savings with minimal investments- yet green marketing actions require company consensus (Crane, 2000a). In this context, it is likely that Red Sea marketing managers are struggling to close the 
gap between their personal values and their managerial behaviours. Part of the problem can be attributed to the very hierarchical structure in many Egyptian organizations, particularly locally managed organisations, where decision-making is highly centralized (Attia et al., 1999; Rice, 2006b; El-Sawah et al., 2008; Shalley et al., 2004), inhibiting employee creativity (Rice, 2006b), and making it unlikely that individuals would take an independent stand in the face of unethical practices (Attia et al., 1999). Thus, engaging in environmental initiatives without the company's support may be perceived as risky, and marketing managers arguably bracket their personal ethics whilst at work and follow the prevailing values and moralities of their organisations (Crane, 2000a; Fineman, 1996). This is consistent with the "positive agency theory" which holds that managers are the agents of shareholders whose interest in wealth maximization must be the only concern for those managers when making decisions (Cannella and Monroe, 1997) - requiring the appropriate organisational conditions to be present before personal values can be expressed. It is also probable that managers from less pro-active (local) companies are less knowledgeable about the concept of green marketing and its potential benefits. Another possible explanation could be methodological. That is, the small sample size made it difficult for the authors to discover this relationship precisely. An element to include in further studies would be decision-making autonomy, to understand if high NEP endorsement denotes a latent interest or simply social desirability.

The last column of Table 5 shows the results of regression analyses conducted to examine the importance of the two variables measuring OEV in explaining green marketing behaviour. OEV had an additional and significant power on companies' GMS, explaining $7 \%$ of the total variance, even after incorporating the control variables. However, this referred to the voluntary, and not profitability-driven 
dimension of GMS, implying that proactive GMS results from in-depth changes of values and belief systems of these organisations. Hotel companies pursuing BER but believing in self-regulation are more likely to incorporate environmental issues in their marketing strategies than traditional profitability-oriented hotels and those who embrace environmental responsibility under governmental intervention. This is mainly because these hotels are governed by higher level chain standards driven by international requirements that go beyond the Egyptian law. This finding is consistent with green marketing research recommending that attempts to incorporate green issues into marketing strategies would not be possible in the absence of a more profound cultural reorientation towards environmental responsibility (Kärnä et al., 2003; Menon and Menon, 1997; Peattie, 1995; Starkey and Crane, 2003). Altruism was indeed identified as an important determinant of environmental proactivity in the hotel industry (Ayuso, 2006; Rivera and de Leon, 2005). The results confirm the idea that companies with a sincere interest in environmental issues might feel the need to communicate their environmental commitment to justify themselves and wash out feelings of guilt (Gonzalez-Benito and Gonzalez-Benito, 2005b). In other words, managers of these companies may also seek moral and cognitive legitimacy from their community and from important stakeholders (Salmi, 2008).

Interestingly, the results indicate that marketing managers overemphasising "profitability orientation" in their values are less likely to engage in more proactive green marketing practices, without clear competitive and financial gains. Arguably they are not able to see the possibility of reaching competitive advantage via implementing GMS, which may be due to a perceived lack of customer or public interest in hotels' environmental behaviours, or dismissing green marketing as "greenwashing". The novelty of the concept /or the lack of knowledge, may also 
influence such orientation. Pearson correlations suggest this correlation to be prevalent in local companies, with few West European clients; local markets are likely to be less environmentally sensitive. Local hotels may, therefore, be pessimistic (or perhaps realistic) about the extent to which a green reputation actually lead to economic benefits. It is generally observed that most local companies in Egypt lack marketing professionalism (Beekun et al., 2008; Marta et al., 2004) and hence find difficulties in accessing markets with special interests. If this is the situation, business survival becomes the core issue for these companies; local companies have to compete intensely for a market share and the environment would not be of course the selling point.

Governmental intervention appeared as not relevant to implementing proactive GMS in the study context. This finding challenges the traditional wisdom that regulatory pressures are determinants of corporate environmental responsiveness (Cashore and Vertinsky, 2000; Hoffman, 1999; Kasim, 2007; Marshall et al., 2005; Rivera, 2004). This may be probably a sign of poor implementation and monitoring of environmental regulations in Egypt, typical of developing countries (Kasim, 2007; Rivera, 2002; Rivera, 2004; Rivera and de Leon, 2005; Utting, 2002). Parnell and Hatem (1999: 405) explain that:

"management in Egypt, like that in other developing countries...is highly dependent on government allocation of resources. Hence, Egyptian management practice cannot be explained solely in terms of individual firm conduct, but must also include the role of the nation-state"

Such an approach may, thus, have some impact on companies' passivity towards green (marketing) initiatives. After all, the Egyptian tourism industry has been growing at a rapid rate during this period, giving the impression that the current business model is appropriate. Accordingly, reactive companies may fail to see the competitive value of green marketing unless the government intervene directly and 
seriously to push the issue. Governmental intervention and monitoring might, therefore, become an important mechanism to provide the impetus for environmentally laggard companies, moving up towards effective promotion of voluntary environmental behaviour.

\section{Conclusions}

This analysis contributes to the organisational greening and green marketing literature by increasing the understanding of how personal and organisational values are associated with GMS proactivity in a developing country. Organizational context and demographic variables are more important in explaining GMS than personal and organisational values. The results support the influence of organisational values on marketing managers' environmental behaviour, but not the influence of personal values. Proactive green companies are genuine in implementing GMS voluntarily, aiming to distance themselves from social critics and to clear feelings of guilt. Such orientation was most common in international chain hotels, implying the importance of formal structures in fostering ethical environments by the use of such formal tools as codes of conduct and training.

Gaps in environmental orientations and behaviours among proactive and reactive companies tend to diminish with proper environmental training and education. This study has shown that governmental intervention has little effect at present, yet it is needed to play a role in encouraging inter-firm co-operation and providing specific educational programmes that help the laggards (mostly local companies) understand the benefits of engaging.

Marketing managers need to realize the growing importance of BER issues and implement marketing strategies that allow them to remain credible in the eyes of interested stakeholders, with or without sacrificing profitability. The dearth of a 
relationship between marketing managers' personal values and companies' green marketing behaviour suggest the need to internally integrate environmental responsibility at the governance, leadership and functional levels. Companies need to foster a culture that encourages empowerment and reward of innovation at all levels of the organization.

Finally, this study is not exempt from limitations that will suggest directions for future research. The results are a snapshot of the green marketing behaviour of hotel companies in one Arab country- the scales should be tested in other industries and in other countries to determine proactive GMS, and the quantitative data relationships need explaining with qualitative research to deepen understanding of the reasons and meanings underlying different behaviours. Furthermore, OEV were measured in this research based on the beliefs of a single respondent from each company assuming that these are typical of the beliefs prevailing in the organizationclearly it is necessary to combine the opinions of more than one source. The value of the study lies in the development of a conceptual framework and replicable methodology that combines personal and organisational values, with organisational contextual and demographic variables, that can be measured against green marketing strategies and operations.

\section{References}

Aguilera, R. V., Rupp, D. E., Williams, C. A. and Ganapathi, J. (2007) Putting the S back in corporate social responsibility: a multilevel theory of social change in organizations. The Academy of Management Review 32 (3), 836-863.

Akaah, I. P. and Lund, D. (1994) The influence of personal and organizational values on marketing professionals' ethical behavior. Journal of Business Ethics 13 (6), 417-430.

Alvarez Gil, M. J., Burgos Jimenez, J. and Céspedes Lorente, J. J. (2001) An analysis 
of environmental management, organizational context and performance of Spanish hotels. Omega 29 (6), 457-471.

Andersson, L. M. and Bateman, T. S. (2000) Individual Environmental Initiative: Championing Natural Environmental Issues in U.S. Business Organizations. Academy of Management Journal 43 (4), 548-570.

Aragón-Correa, J. A. (1998) Strategic Proactivity and Firm Approach to the Natural Environment. Academy of Management Journal 41 (5), 556-567.

Attia, A., Shankarmahesh, M. N. and Singhapakdi, A. (1999) Marketing ethics: a comparison of American and Middle-Eastern marketers. International Business Review 8 (5-6), 611-632.

Ayuso, S. (2006) Adoption of Voluntary Environmental Tools for Sustainable Tourism: Analysing the Experience of Spanish Hotels. Corporate Social Responsibility and Environmental Management 13 (4), 207-720.

Baker, W. E. and Sinkula, J. M. (2005a) Environmental Marketing Strategy and Firm Performance: Effects on New Product Performance and Market Share. JournalAcademy of Marketing Science 33461-475.

Baker, W. E. and Sinkula, J. M. (2005b) Market Orientation and the New Product Paradox. Journal of Product Innovation Management 22 (6), 483-502.

Banerjee, S. B. (1999) Corporate Environmentalism and the Greening of Strategic Marketing. In M. Charter, \& J. M. Polonsky (Eds.), Greener Marketing - A Global Perspective on Greening Marketing Practice (pp. 16-40). Sheffield: Greenleaf Publishing.

Banerjee, S. B., Iyer, E. S. and Kashyap, R. K. (2003) Corporate Environmentalism: Antecedents and Influence of Industry Type. Journal of Marketing 67 (2), 106122.

Bansal, P. (2003) From Issues to Actions: The Importance of Individual Concerns and Organizational Values in Responding to Natural Environmental Issues. Organization Science 14 (5), 510-527.

Bansal, P. and Roth, K. (2000) Why Companies Go Green: A Model of Ecological Responsiveness. Academy of Management Journal 43 (4), 717-737.

Batra, A. (2006) Tourism Marketing for Sustainable Development. ABAC Journal 26 (1), 59-65.

Beekun, R. I., Hamdy, R., Westerman, J. W. and HassabElnaby, H. R. (2008) An Exploration of Ethical Decision-making Processes in the United States and Egypt. Journal of Business Ethics 82 (3), 587-605.

Berkhout, T. and Rowlands, I. H. (2007) The Voluntary Adoption of Green Electricity 
by Ontario-Based Companies: The Importance of Organizational Values and Organizational Context. Organization and Environment 20281-303.

Bohdanowicz, P. (2006) Environmental awareness and initiatives in the Swedish and Polish hotel industries-survey results. International Journal of Hospitality Management 25 (4), 662-682.

Bohdanowicz, P. (2007) A Case Study of Hilton Environmental Reporting as a Tool of Corporate Social Responsibility Tourism Review International 11 (2), 115131.

Buil-Carrasco, I., Fraj-Andres, E. and Matute-Vallejo, J. (2008) Corporate environmentalism strategy in the Spanish consumer product sector: a typology of firms. Business Strategy and the Environment 17 (6), 350-368.

Cannella, A. A. and Monroe, M. J. (1997) Contrasting Perspectives on Strategic Leaders: Toward a More Realistic View of Top Managers. Journal of Management 23 (3), 213-237.

Carmona-Moreno, E., Céspedes-Lorente, J. and De Burgos-Jimenez, J. (2004) Environmental Strategies in Spanish Hotels: Contextual Factors and Performance. Service Industries Journal. 24 (3), 101-130.

Cashore, B. and Vertinsky, I. (2000) Policy networks and firm behaviours: Governance systems and firm reponses to external demands for sustainable forest management. Policy Sciences 33 (1), 1-30.

Chamorro, A. and Bañegil, T. M. (2006) Green marketing philosophy: a study of Spanish firms with ecolabels. Corporate Social Responsibility and Environmental Management 13 (1), 11-24.

Charter, M. (1992) Greener marketing: a responsible approach to business. Sheffield: Greenleaf Publishing.

Christmann, P. and Taylor, G. (2001) Globalization and the Environment: Determinants of Firm Self-Regulation in China. Journal of International Business Studies 32 (3), 439-458.

Clark, C. F., Kotchen, M. J. and Moore, M. R. (2003) Internal and external influences on pro-environmental behavior: Participation in a green electricity program. Journal of Environmental Psychology 23 (3), 237-246.

Crane, A. (2000a) Facing the backlash: green marketing and strategic reorientation in the 1990s. Journal of Strategic Marketing 8 (3), 277-296.

Crane, A. (2000b) Marketing, Morality and the Natural Environment. London: Routledge.

Cummings, L. S. (2008) Managerial attitudes toward environmental management within Australia, the Peoples Republic of China and Indonesia. Business Strategy and the Environment 17 (1), 16-29. 
Deng, J., Walker, G. J. and Swinnerton, G. (2006) A Comparison of Environmental Values and Attitudes Between Chinese in Canada and Anglo-Canadians. Environment and Behavior 3822-47.

Diekmann, A. and Franzen, A. (1999) The Wealth of Nations and Environmental Concern. Environment and Behavior 31 (4), 540-549.

Dinan, C. and Sargeant, A. (1998) Tourism Marketing: Adding Value through sustainability. In C. Gilligan, \& S. Lawson (Eds.), Academy of Marketing (pp. 656-657). Sheffield: Sheffield Business School.

Drumwright, M. E. (1994) Socially Responsible Organizational Buying: Environmental Concern as a Non Economic Buying Criterion. Journal of Marketing 58 (3), 1-19.

Dunlap, R., Liere, K. V., Mertig, A. and Jones, R. E. (2000) Measuring Endorsement of the New Ecological Paradigm: A Revised NEP Scale. Journal of Social Issues 56 (3), 425-442.

Egri, C. R. and Herman, S. (2000) Leadership in the North American Environmental Sector: Values, Leadership Styles, and Contexts of Environmental Leaders and Their Organizations. Academy of Management Journal 43 (4), 571-604.

El-Sawah, S. E., Tharwat, A. A. and Rasmy, M. H. (2008) A quantitative model to predict the Egyptian ERP implementation success index. Business Process Management Journal 14 (3), 288-306.

Ewert, A. and Baker, D. (2001) Standing for Where You Sit: An Exploratory Analysis of the Relationship Between Academic Major and Environmental Beliefs. Environment and Behavior 33 (5), 687-707.

Fineman, S. (1996) Emotional Subtexts in Corporate Greening. Organization Studies 17 (3), 479-500.

Flannery, B. L. and May, D. R. (2000) Environmental Ethical Decision Making in the U.S. Metal-Finishing Industry. Academy of Management Journal 43 (4), 642662.

Font, X. and Buckley, R. (2001) Tourism ecolabelling: certification and promotion of sustainable management. Wallingford, Oxon: CABI.

Font, X. and Carey, B. (2005) Marketing sustainable tourism products. Florence: Regione Toscana and United Nations Environment Programme.

Fryxell, G. E. and Lo, C. W. (2003) The Influence of Environmental Knowledge and Values on Managerial Behaviours on Behalf of the Environment: An Empirical Examination of Managers in China. Journal of Business Ethics 46 (1), 45-69.

Fuller, D. (1999) Sustainable marketing: managerial-ecological issues. Thousand Oaks: SAGE. 
González-Benito, J. and González-Benito, O. (2005a) An Analysis of the Relationship between Environmental Motivations and ISO14001 Certification. British Journal of Management 16 (2), 133-148.

González-Benito, J. and González-Benito, O. (2005b) A study of the motivations for the environmental transformation of companies. Industrial Marketing Management 34 (5), 462-475.

González-Benito, J. and González-Benito, O. (2006) The role of stakeholder pressure and managerial values in the implementation of environmental logistics practices. International Journal of Production Research 44, 1353-1373.

González, M. and León, C. J. (2001) The adoption of environmental innovations in the hotel industry of Gran Canaria. Tourism Economics 7 (2), 177-190.

Grant, J. (2007) The green marketing manifesto: Wiley.

Hart, S. L. (1995) A Natural-Resource-Based View of the Firm. Academy of Management Review 20 (4), 986-1014.

Hambrick, D. C. and Finkelstein, S. (1987) Managerial discretion: A bridge between polar views of organizational outcomes. Research in Organizational Behavior 9, 369-406.

Henriques, I. Y. and Sadorsky, P. (1996) The Determinants of an Environmentally Responsible Firms: An Empirical Approach. Journal of Environmental Economics and Management 30, 381-395.

Henriques, I. Y. and Sadorsky, P. (1999) The Relationship between Environmental Commitment and Managerial Perceptions of Stakeholder Importance. Academy of Management Journal 42 (1), 87-99.

Hoffman, A. J. (1999) Institutional Evolution and Change: Environmentalism and the U.S. Chemical Industry. Academy of Management Journal 42 (4), 351-371.

Honey, M. (2002) Ecotourism \& certification: setting standards in practice. Washington DC: Island Press.

Hudson, S. and Miller, G. A. (2005) The responsible marketing of tourism: the case of Canadian Mountain Holidays. Tourism Management 26 (2), 133-142.

Jameson, S. C., Ammar, M. S. A., Saadalla, E., Mostafa, H. M. and Riegl, B. (2007) A Quantitative Ecological Assessment of Diving Sites in the Egyptian Red Sea During a Period of Severe Anchor Damage: A Baseline for Restoration and Sustainable Tourism Management. Journal of Sustainable Tourism 15, 309323.

Kärnä, J., Hansen, E. and Juslin, H. (2003) Social responsibility in environmental marketing planning. European Journal of Marketing 37 (5/6), 848-871. 
Kasim, A. (2006) The Need for Business Environmental and Social Responsibility in the Tourism Industry. International Journal of Hospitality and Tourism Administration 7 (1), 1-22.

Kasim, A. (2007) Corporate Environmentalism in the Hotel Sector: Evidence of Drivers and Barriers in Penang, Malaysia. Journal of Sustainable Tourism 15 (6), 680-699.

Kasim, A. (2008) Socially Responsible Hospitality and Tourism Marketing. In H. Oh, \& A. Pizam (Eds.), Handbook of Hospitality Marketing (pp. 32-58). Boston, MA: Butterworth-Heinemann.

Kemmelmeier, M., Krol, G. and Kim, Y. H. (2002) Values, Economics, and Proenvironmental Attitudes in 22 Societies. Cross Cultural Research 36 (3), 256-285.

Key, S. and Popkin, S. J. (1998) Integrating ethics into the strategic management process: doing well by doing good. Management Decision 36 (5), 331-338.

Kirk, D. (1996) Environmental management for hotels: a student's handbook. Oxford: Butterworth-Heinemann.

Kotchen, M. J. and Reiling, S. D. (2000) Environmental attitudes, motivations, and contingent valuation of nonuse values: a case study involving endangered species. Ecological Economics 32 (1), 93-107.

Laufer, W. S. (2003) Social Accountability and Corporate Greenwashing. Journal of Business Ethics 43 (3), 253-261.

Lee, S. and Park, S-Y. (2009) Do socially responsible activities help hotels and casinos achieve their financial goals? International Journal of Hospitality Management 28, 105-112.

Marshall, R. S., Cordano, M. and Silverman, M. (2005) Exploring Individual and Institutional Drivers of Proactive Environmentalism in the U.S. Wine Industry. Business Strategy and the Environment 14 (2), 92-109.

Marta, J. K., Singhapakdi, A., Attia, A. and Vitell, S. J. (2004) Some important factors underlying ethical decisions of Middle-Eastern marketers. International Marketing Review 21 (1), 53-67.

Menon, A. and Menon, A. (1997) Enviropreneurial Marketing Strategy: The Emergence of Corporate Environmentalism as Market Strategy. Journal of Marketing 61 (1), 51-67.

Miles, M. P., and Covin, J. G. (2000) Environmental marketing: A source of reputational, competitive, and financial advantage. Journal of Business Ethics 23 (3), 299-311. 
Moon, S. g. and deLeon, P. (2007) Contexts and Corporate Voluntary Environmental Behaviors: Examining the EPA's Green Lights Voluntary Program. Organization and Environment 20, 480-496.

Mostafa, M. M. (2007a) Gender differences in Egyptian consumers' green purchase behaviour: the effects of environmental knowledge, concern and attitude. International Journal of Consumer Studies 31 (3), 220-229.

Mostafa, M. M. (2007b) A hierarchical analysis of the green consciousness of the Egyptian consumer. Psychology and Marketing 24 (5), 445-473.

Ottman, J. (1998) Green Marketing: Opportunity for Innovation. Chicago: NTC Business Books.

Parnell, J. A. and Hatem, T. (1999) Cultural Antecedents of Behavioural Differences between American and Egyptian Managers. Journal of Management Studies 36 (3), 399-418.

Peattie, K. (1995) Environmental marketing management: meeting the green challenge. London: Pitman Publishing.

Peattie, K. (1999) Rethinking marketing. In M. Charter, \& J. M. Polonsky (Eds.), Greener Marketing - A Global Perspective on Greening Marketing Practice (pp. 57-70). Sheffield: Greenleaf Publishing.

Polonsky, M. J. and Rosenberger, P. J. (2001) Reevaluating green marketing: a strategic approach. Business Horizons 44 (5), 21-30.

Porter, M. and van der Linde, C. (1995) Green and Competitive: Ending the Stalemate. Harvard Business Review 73 (5), 120-134.

Prakash, A. (2001) Why Do Firms Adopt 'Beyond-Compliance' Environmental Policies? Business Strategy and the Environment 10 (5), 286-299.

Pujari, D. and Wright, G. (1996) Developing environmentally conscious product strategies: a qualitative study of selected companies in Germany and Britain. Marketing Intelligence and Planning 14 (1), 19-28.

Ramus, C. A. and Steger, U. (2000) The Roles of Supervisory Support Behaviors and Environmental Policy in Employee "Ecoinitiatives" at Leading-Edge European Companies. Academy of Management Journal 43 (4), 605-626.

Rice, G. (2006a) Individual values, Organizational Context, and self-perceptions of employee creativity: Evidence from Egyptian organizations. Journal of Business Research 59 (2), 233-241.

Rice, G. (2006b) Pro-environmental Behavior in Egypt: Is there a Role for Islamic Environmental Ethics? Journal of Business Ethics 65 (4), 373-390. 
Rivera, J. (2002) Assessing a voluntary environmental initiative in the developing world: The Costa Rican Certification for Sustainable Tourism. Policy Sciences 35 (4), 333-360.

Rivera, J. (2004) Institutional pressures and voluntary environmental behavior in developing countries: evidence from the Costa Rican hotel industry. Society and Natural Resources 17, 779-797.

Rivera, J. and de Leon, P. (2005) Chief Executive Officers and voluntary environmental performance: Costa Rica's Certification for Sustainable Tourism. Policy Sciences 38 (2-3), 107-127.

Russo, M. V. and Fouts, P. A. (1997) A Resource-Based Perspective on Corporate Environmental Performance and Profitability. Academy of Management Journal 40 (3), 534-559.

Salmi, O. (2008) Drivers for adopting environmental management systems in the post-Soviet mining industry. International Environmental Agreements: Politics, Law and Economics 8 (1), 51-77

Shaalan, I. M. (2005) Sustainable tourism development in the Red Sea of Egypt threats and opportunities. Journal of Cleaner Production 1383-87.

Shalley, C. E., Zhou, J. and Oldham, G. R. (2004) The Effects of Personal and Contextual Characteristics on Creativity: Where Should We Go from Here? Journal of Management 30 (6), 933-958.

Sharma, S. (2000) Managerial Interpretations and Organizational Context as Predictors of Corporate Choice of Environmental Strategy. Academy of Management Journal 43 (4), 681-697.

Sharma, S. and Henriques, I. (2005) Stakeholder Influences on Sustainability Practices in the Canadian Forest Products Industry. Strategic Management Journal 26, 159-180.

Sharma, S., Pablo, A. L. and Vredenburg, H. (1999) Corporate Environmental Responsiveness Strategies: The Importance of Issue Interpretation and Organizational Context. Journal of Applied Behavioral Science 35 (1), 87-108.

Shrivastava, P. (1995a) Environmental Technologies and Competitive Advantage. Strategic Management Journal 16 (Spi), 183-200.

Shrivastava, P. (1995b) The Role of Corporations in Achieving Ecological Sustainability. Academy of Management Review 20 (4), 936-960.

Snelgar, R. S. (2006) Egoistic, altruistic, and biospheric environmental concerns: Measurement and structure. Journal of Environmental Psychology 26 (2), 87-99.

Starkey, K. and Crane, A. (2003) Toward Green Narrative: Management and the Evolutionary Epic. Academy of Management Review 28 (2), 220-237. 
Tzschentke, N., Kirk, D. and Lynch, P. A. (2004) Reasons for going green in serviced accommodation establishments. International Journal of Contemporary Hospitality Management 16 (2), 116-124.

Utting, P. (2002) Towards corporate environmental responsibility? In P. Utting (Ed.), The greening of business in developing countries: Rhetoric, Realities and Prospects (pp. 1-13). London: Zed Books Limited on behalf on the United Nations Research Institute for Social Development.

Wasik, J. (1996) Green marketing and management: a global perspective. Cambridge, USA: Blackwell.

Webster, K. (2000) Environmental management in the hospitality industry: a guide for students and managers. London: Cassell.

Welford, R. (1995) Environmental strategy and sustainable development: the corporate challenge for the 21st century. London: Routledge.

Wheeler, M. (1995) Tourism Marketing Ethics: An Introduction. International Marketing Review 12 (4), 38-49.

Wiersema, M. F. and Bantel, K. A. (1993) Top Management Team Turnover as an Adaptation Mechanism: The Role of the Environment. Strategic Management Journal 14 (7), 485. 
Table 1: Dimensions of personal environmental values (PEV) *

\begin{tabular}{|l|c|c|c|}
\hline \multicolumn{1}{|c|}{ Item } & $\begin{array}{c}\text { Mean } \\
\text { (SD) } \\
\mathrm{n}=89\end{array}$ & $\begin{array}{c}\text { HEP } \\
\alpha=.811\end{array}$ & $\begin{array}{c}\text { NEP } \\
\alpha= \\
0.843\end{array}$ \\
\hline $\begin{array}{l}\text { (1) We are approaching the limit of the } \\
\text { number of people the earth can support }\end{array}$ & $\begin{array}{c}4.13 \\
(0.54)\end{array}$ & -0.034 & $\mathbf{0 . 8 0 0}$ \\
\hline $\begin{array}{l}\text { (2) The balance of nature is very delicate and } \\
\text { easily upset }\end{array}$ & $\begin{array}{c}4.05 \\
(0.53)\end{array}$ & -0.167 & $\mathbf{0 . 8 2 0}$ \\
\hline $\begin{array}{l}\text { (3) Plants and animals have much right as } \\
\text { humans to exist }\end{array}$ & $\begin{array}{c}4.21 \\
(0.55)\end{array}$ & -0.117 & $\mathbf{0 . 8 0 8}$ \\
\hline $\begin{array}{l}\text { (4) If things continue on their present course } \\
\text { we will soon experience a major ecological } \\
\text { catastrophe }\end{array}$ & $\begin{array}{c}3.98 \\
(0.57)\end{array}$ & -0.203 & $\mathbf{0 . 8 1 4}$ \\
\hline $\begin{array}{l}\text { 5) Human ingenuity will ensure that we do } \\
\text { NOT make the earth unliveable }\end{array}$ & $\begin{array}{c}1.87 \\
(0.49)\end{array}$ & $\mathbf{0 . 7 6 2}$ & -0.236 \\
\hline $\begin{array}{l}\text { (6) The balance of the nature is strong enough } \\
\text { to cope with the impacts of modern industrial } \\
\text { nations }\end{array}$ & $\begin{array}{c}1.85 \\
(0.57)\end{array}$ & $\mathbf{0 . 7 4 4}$ & -0.175 \\
\hline $\begin{array}{l}\text { (7) The so-called "ecological crises" facing } \\
\text { humankind has been greatly exaggerated }\end{array}$ & $\begin{array}{c}1.85 \\
(0.53)\end{array}$ & $\mathbf{0 . 7 2 0}$ & -0.157 \\
\hline $\begin{array}{l}\text { (8) Humans were meant to rule over the rest } \\
\text { of nature }\end{array}$ & $\begin{array}{c}1.80 \\
(0.49)\end{array}$ & $\mathbf{0 . 7 3 0}$ & -0.142 \\
\hline $\begin{array}{l}\text { (9) Humans will eventually learn enough } \\
\text { about how nature works to be able to control } \\
\text { it }\end{array}$ & $\begin{array}{c}1.82 \\
(0.55)\end{array}$ & $\mathbf{0 . 7 4 9}$ & 0.076 \\
\hline
\end{tabular}

*Loadings of 0.40 and above are in bold 
Table 2: Dimensions of organisational environmental values (OEV)*

\begin{tabular}{|c|c|c|c|}
\hline Item & $\begin{array}{l}\text { Mean } \\
(\mathrm{SD}) \\
\mathrm{n}=89\end{array}$ & $\begin{array}{c}\text { Profitability- } \\
\text { orientation } \\
\alpha=0.809\end{array}$ & $\begin{array}{l}\text { Voluntary } \\
\text { vs. Gov } \\
\alpha=0.631\end{array}$ \\
\hline $\begin{array}{l}\text { (1) Hotels should simply comply with } \\
\text { government regulations to be more } \\
\text { responsible }\end{array}$ & $\begin{array}{c}3.44 \\
(1.31)\end{array}$ & -0.268 & 0.783 \\
\hline $\begin{array}{l}\text { (2) Hotel occupancy levels are more } \\
\text { important than environmental issues }\end{array}$ & $\begin{array}{c}2.73 \\
(1.10) \\
\end{array}$ & 0.656 & -0.106 \\
\hline $\begin{array}{l}\text { (3) It is better to ignore environmental } \\
\text { issues (e.g. linen program) that could } \\
\text { impact on guests experience as hotels are } \\
\text { driven by market preferences }\end{array}$ & $\begin{array}{c}2.67 \\
(1.28)\end{array}$ & 0.771 & 0.03 \\
\hline $\begin{array}{l}\text { (4) Environmental management/ marketing } \\
\text { in the hotel industry is public relations } \\
\text { invention to get cordial relations with } \\
\text { stakeholders }\end{array}$ & $\begin{array}{c}3.24 \\
(1.22)\end{array}$ & 0.635 & 0.244 \\
\hline $\begin{array}{l}\text { (5) Environmentally responsiveness is the } \\
\text { right thing to do for sustainability of hotels }\end{array}$ & $\begin{array}{c}4.48 \\
(0.62)\end{array}$ & -0.142 & -0.612 \\
\hline $\begin{array}{l}\text { 6) Governmental intervention is important } \\
\text { to encourage hotels to... }\end{array}$ & $\begin{array}{l}3.34 \\
1.34 \\
\end{array}$ & -0.128 & 0.810 \\
\hline $\begin{array}{l}\text { (7) A hotel should wait and see what } \\
\text { competitors are benefiting before } \\
\text { introducing environmental strategies }\end{array}$ & $\begin{array}{c}2.76 \\
(1.06)\end{array}$ & 0.811 & .044 \\
\hline $\begin{array}{l}\text { (8) Hotels do not have the right to damage } \\
\text { the environment just to satisfy their needs }\end{array}$ & $\begin{array}{r}4.17 \\
(0.66) \\
\end{array}$ & -0.280 & -0.481 \\
\hline $\begin{array}{l}\text { (9) It is cost reduction that may drive a } \\
\text { hotel to implement environmental } \\
\text { initiatives }\end{array}$ & $\begin{array}{c}2.91 \\
(1.08)\end{array}$ & 0.625 & -0.210 \\
\hline $\begin{array}{l}\text { (10) The sole function of hotel } \\
\text { management/marketing is to fulfil the } \\
\text { owner/shareholders' interests }\end{array}$ & $\begin{array}{c}2.89 \\
(1.16)\end{array}$ & 0.764 & 0.121 \\
\hline
\end{tabular}

*Loadings of 0.40 and above are in bold 
Table 3: Dimension of green marketing strategies (GMS)*

\begin{tabular}{|c|c|c|c|}
\hline Item & Mean (sd) & $\begin{array}{c}\text { Green marketing } \\
\text { strategies } \\
\alpha=89\end{array}$ & $\begin{array}{c}\mathrm{r}_{i}-\mathrm{i} \\
\alpha=0.891\end{array}$ \\
\hline
\end{tabular}

*Loadings of 0.40 and above are in bold 


\begin{tabular}{|c|c|c|c|}
\hline $\begin{array}{l}\text { (1) Importance of environmental friendliness when considering product/service } \\
\text { competitiveness }\end{array}$ & $\begin{array}{l}3.01 \\
(1.04)\end{array}$ & 0.764 & 0.683 \\
\hline (2) Importance of customer environmental awareness in targeting/segmenting decisions & $\begin{array}{c}3.15 \\
(1.20)\end{array}$ & 0.790 & 0.708 \\
\hline (3) Emphasis of environmental friendliness in the chain/hotel positioning & $\begin{array}{c}3.47 \\
(1.11)\end{array}$ & 0.780 & 0.702 \\
\hline (4) The impact of environmental issues on communication campaigns & $\begin{array}{c}3.28 \\
(1.03)\end{array}$ & 0.794 & 0.723 \\
\hline $\begin{array}{l}\text { (5) The frequency of inviting from and/or providing environmental information to } \\
\text { environmental stakeholders }\end{array}$ & $\begin{array}{c}2.80 \\
(1.12)\end{array}$ & 0.685 & 0.596 \\
\hline 6) The impact that environmental issues have on service/ product pricing (e.g. green premium) & $\begin{array}{c}2.58 \\
(1.06)\end{array}$ & 0.643 & 0.548 \\
\hline $\begin{array}{l}\text { (7) The influence of environment issues on selections of distribution channels (e.g. tour } \\
\text { operators; travel agencies) }\end{array}$ & $\begin{array}{c}2.77 \\
(1.04)\end{array}$ & 0.681 & 0.594 \\
\hline (8) Redirecting clients towards sustainable holidays (e.g. Not to harm the coral reefs etc.) & $\begin{array}{c}3.93 \\
(1.19)\end{array}$ & 0.704 & 0.619 \\
\hline $\begin{array}{l}\text { (9) Importance of environmental friendliness in public relations campaigns (e.g. the local } \\
\text { community) }\end{array}$ & $\begin{array}{c}3.37 \\
(1.20)\end{array}$ & 0.737 & 0.656 \\
\hline
\end{tabular}


Table 4: The Relationship between independent variables (predictors)

\begin{tabular}{|c|c|c|c|c|c|c|c|c|c|c|}
\hline & 1 & 2 & 3 & 4 & 5 & 6 & 7 & 8 & 9 & 10 \\
\hline 1-Manager's tenure & 1 & & & & & & & & & \\
\hline 2-Manager's age & 0.069 & 1 & & & & & & & & \\
\hline 3- Manager's education & -0.032 & $0.220 * *$ & 1 & & & & & & & \\
\hline 4-Manager's gender & 0.066 & $-0.329 * * *$ & -0.092 & 1 & & & & & & \\
\hline 5-Chain Affiliation & 0.048 & -0.147 & 0.009 & $0.336^{* * *}$ & 1 & & & & & \\
\hline 6- Priority Markets & -0.106 & $-0.184 *$ & 0.029 & $0.329 * * *$ & $0.707 * * *$ & 1 & & & & \\
\hline 7- HEP & 0.093 & -0.080 & 0.161 & 0.085 & 0.090 & -0.011 & 1 & & & \\
\hline 8- NEP & -0.039 & 0.041 & 0.023 & 0.013 & $0.226^{* *}$ & $0.218^{* *}$ & $-0.319 * * *$ & 1 & & \\
\hline $\begin{array}{l}\text { 9- Profitability- } \\
\text { orientation }\end{array}$ & 0.025 & 0.032 & -0.074 & 0.082 & 0.117 & 0.080 & 0.128 & 0.044 & 1 & \\
\hline $\begin{array}{l}\text { 10-Voluntary vs. } \\
\text { Governmental } \\
\text { intervention }\end{array}$ & 0.003 & -0.040 & 0.146 & 0.184 & $0.680 * * *$ & $0.688 * * *$ & 0.074 & $0.229 * *$ & $\begin{array}{c}0.04 \\
3\end{array}$ & 1 \\
\hline
\end{tabular}

*** Correlation is significant at the 0.01 level (2-tailed) $* *$ Correlation is significant at the 0.05 level (2-tailed) $*$ Correlation is significant at the 0.1 level (2-tailed). 
Table 5: Regression coefficient of model predicting GMS in the sampled companies

\begin{tabular}{|c|c|c|c|}
\hline & Explanatory & Explanatory & Explanatory \\
\hline & Model 1 & Model 2 & Model 3 \\
\hline & GMS & GMS & GMS \\
\hline & $\beta$ Step1 & $\beta$ Step2 & $\beta$ Step3 \\
\hline \multirow{3}{*}{$\begin{array}{l}\text { Constant } \\
\text { Age } \\
\text { Industry tenure }\end{array}$} & & & \\
\hline & $-0.130 *$ & $-0.126^{*}$ & $-0.156 * *$ \\
\hline & -0.024 & -0.026 & -0.039 \\
\hline \multirow{2}{*}{$\begin{array}{l}\text { Education (Business } \\
\text { Adm vs. others } \\
\text { Gender }\end{array}$} & $0.142 * *$ & $0.137 * *$ & $0.107 *$ \\
\hline & 0.102 & 0.099 & 0.121 \\
\hline $\begin{array}{l}\text { Western European } \\
\text { markets }\end{array}$ & $0.470 * * *$ & $0.477 * * *$ & $0.301 * * *$ \\
\hline Chain affiliation & $0.313 * * *$ & $0.313 * * *$ & $0.158^{*}$ \\
\hline HEP & & 0.024 & -0.011 \\
\hline NEP & & -0.022 & -0.53 \\
\hline $\begin{array}{l}\text { Profitability- } \\
\text { orientation }\end{array}$ & & & 0.082 \\
\hline $\begin{array}{l}\text { Business voluntary- } \\
\text { based values }\end{array}$ & & & $0.395 * * *$ \\
\hline $\mathrm{R}^{2}$ at each step & 0.664 & 0.665 & 0.735 \\
\hline$\Delta \mathrm{R}^{2}$ at each step & 0.65 .7 & 0.001 & 0.070 \\
\hline
\end{tabular}

Note $^{1}$ : $\beta$ 's are the standardized coefficients; $* P<0.10$. ${ }^{* *} P<0.05$. $* * * P<0.01$. 